this principle, Dr. Ludwig Mond not only made the Solvay ammonia-soda process a commercial and technical success, but also showed by what means the science of physical chemistry could be studied practically and developed in a works instead of in a laboratory.

Sir Robert Mond suggested that this was his father's great contribution to human progress, and those who took part in the numerous visitis to works and factories during the week found much to justify Sir Robert's assertion. It was equally supported by papers presented to the meeting such as Dr. R. Houwink's address to the Plastics Group on "Synthetic Resins, their Formation, Properties and Possibilities", Dr. L. H. Lampitt's on "Food Package and the Consumer" at the Food Group Congress held jointly with the Royal Sanitary Institute at Southport, or Mr. R. G. Batson's address to the Road and Building Materials Group on "Scientific Research and the Highway Engineer".

All these papers and discussions emphasized the way in which exact measurements by physical methods are laying the foundations for future advance. Dr. Houwink, discussing future developments, said that one of the most urgent requirements is for stronger, more elastic, more shock resistant and electrically improved products, and referred to the possibility of improving the properties of shellac so that competition with resins like those of the phenol-formaldehyde type become possible again. Dr. Lampitt referred to the way in which growing public appreciation of the importance of hygiene has led to fresh demands for packing materials which the chemist has been able to meet.
The address for which the Liverpool meeting will be most remembered, however, is that of the president, Mr. W. A. S. Calder, on July 7, on "The Chemist as World Citizen". Mr. Calder linked up the chemist and his training to acquire and face facts with his wide responsibilities in the world to-day. One of the chief causes of the dangers to freedom and progress is the utter ignoring of facts, and Mr. Calder protested strongly that the chemist is not the destroyer which the irresponsible Press represents him to be. It is a lamentable fact, however, that we are all susceptible to the poisonous virus of newspaper propaganda. No one capable of thought can fail to admit that no one nation is ever entirely responsible for a war, and Mr. Calder pointed out that the training of a chemist should teach him the impossibility of being always right. Chemists cannot escape the responsibility of seeing that the danger of refusing to face facts is duly impressed upon our politicians.

Another direction in which the chemist can play a part as a world citizen is that of the prevention of accidents. The chemist and engineer are qualified by their training to be of special service in anticipating risks and thus preventing accidents. Many accidents still occur which could not be possible if those in charge of affairs fully realized their responsibility. Men are even exposed to unnecessary risks which they are expected to avoid by compliance with impossible orders for their own safety, and Mr. Calder expressed the hope that the interchange of details of accidents already taking place between several countries might become world-wide.

\title{
Coral Reef Ecology at Low Isles
}

$\mathrm{T}^{\mathrm{H}}$ HIS fine contribution* to the series of reports on the Great Barrier Reef Expedition of 1928-29 is chiefly concerned with accounts of three traverses across the reefs at Low Isles. Its production is the result of a collaboration between several workers; Prof. T. A. Stephenson originally chose the traverses; physical and chemical data were provided by $\mathbf{M r}$. A. P. Orr, and level sections by Mr. M. A. Spender. The bulk of the work, however, fell to Dr. Fraser and Dr. S. M. Manton, who jointly enumerated the organisms present, while the latter is responsible for drawing up this report.

Along each traverse a strip of reef one yard in width was examined. The first traverse, more than 1,000 feet long, started from a Thalamita flat inside the reef and crossing a shallow moat, passed over a boulder tract to descend the seaward slope of the reef to the muddy sea-floor at about twenty feet below datum. The second traverse, about half the length of the first, crossed a portion of the reef where the contoux of the sea-floor was rather irregular. The third traverse on the windward side of the reef could not be worked in detail on account of the roughness of the water; but such observations as were made are nevertheless of much interest.

* British Museum (Natural History). Great Barrier Reef Expedition, 1928-29. Sclentiflc Reports, vol. 3, No. 10 : Ecological Surveys of Coral Reefs. By Dr. S. M. Manton. Pp. 273-312 +16 plates. (London : British Museum (Natural History), 1935.) 108.
The results of these surveys are given in a number of graphs that permit easy comparisons to be made of the distribution of corals and algæ, both as regards abundance of individuals and of species. Algæ were abundant only in the moat and on the inshore part of the second traverse; they were almost absent from the seaward slopes of all three. Coral growth was vigorous in the deeper part of the moat-where there is always nearly a foot of water at low tide-as well as on the seaward slopes of the traverses below the datum line. In the moat physical conditions were extreme, especially as regards temperature and to a considerable extent silting; the association of species living there was hence not the same as that outside. Montipora ramosa was the dominant coral in the moat, indeed being restricted to that situation, whereas the Acroporas, species sensitive to heat and silt, were almost entirely confined to the seaward slopes.

One of the more important points brought out is the influence of silt on the distribution of corals. It seems clear that whereas some species are well able to withstand a fair amount of silting, others are killed off by very little. Silt is evidently a limiting factor, and it is in turn correlated, of course, with water movement.

In addition to the traverses at Low Isles, small isolated areas on the Outer Barrier Reef were examined and are described here for comparison. 
The different physical conditions there are primarily responsible for the change in the character of the fauna as compared with that at Low Isles.

This report is most beautifully illustrated by a series of large-scale maps in picture form, showing in detail the distribution of corals and other organisms on small selected areas of the traverses or on portions of the Outer Barrier Reef. These maps show evidence of lavish care and attention both in the preliminary drawings and in the measurements necessary to produce them, as well as in the skilful draughtsmanship that has produced the finished plates. They should be of great value to all students of coral reef ecology.

\section{Diesel Fuels and Engineering}

$\mathrm{A}^{\mathrm{T}}$

$\mathrm{T}$ the first overseas meeting of the Institution of Petroleum Technologists held in Holland on May 8-11, a series of papers was read on diesel fuels and diesel engineering.

Among papers presented for discussion was one by Ir. W. Hupkes on "Diesel-Electric Traction on the Netherlands Railways". Of particular interest in this paper is a clear exposition of facts leading to selection of diesel-electric trains for the frequent and regular conveyance of passengers in the Netherlands. The triple-articulated diesel-electric engine chosen was designed specifically to meet circumstances of accommodation, coupling, speed, rapid acceleration and open-air storage when not in service. Full details are given of the car arrangement ultimately decided upon, motive power, performance, braking, automatic coupling, heating and ventilation.

Ir. G. J. Lugt in his paper on the "Design of Fuel Injectors for Diesel Engines" described the two methods of fuel injection, mechanical and pneumatic, and indicated the function of the injector as being the distribution of the fuel over the air in the compression space of the cylinder. $\mathrm{He}$ then devoted himself to closed mechanical injectors as being almost exclusively used by diesel engineers. $\mathrm{He}$ concluded with the remark that there is now little need for individual design of injectors for diesel engines as they have become to all intents and pur. poses a standard fitting.

Mr. C. H. Barton in his paper on "Diesel Fuel Specifications" pointed out the necessity for such specifications in the classification of fuels into grades and in the indication of desirable properties in par. ticular grades. He described tests commonly adopted in fuel specifications and indicated their significance.

A joint paper by Ir. G. D. Boerlage, Ir. J. J. Broeze, L. J. Le Mesurier and R. Stansfield, on the "Correlation of Tests on the Ignition Quality of Diesel Fuels, carried out at Delft and Sunbury", was the outcome of differences found in the two laboratories regarding the rating in terms of cetene numbers of some commercial fuels. A great deal of work was involved before agreement was reached, and the results of this collaboration are of major importance as providing a feasible technique for the accurate determination of ignition quality of diesel fuels.

\section{Training of the Engineer in the U.S.A.}

\begin{abstract}
A PAPER on the training of the young engineer by R. E. Hellmund, of the Westinghouse Company, just published by the American Institute of Electrical Engineers, takes into account the changing conditions of the industry recovering from the great depression. It was discussed at the summer convention of the American Institute of Electrical Engineers at Pasadena on June 26, 1936.

The disorganization of industry brought about in the United States and elsewhere by bad times has resulted in many radical suggestions being made in connexion with engineering education, and $\mathrm{Mr}$. Hellmund has noted a tendency to discard good methods with bad. Even if it were desirable for the good of humanity to retard the introduction of labour-saving devices with the object of avoiding unemployment, it would not be advisable. Every engineer employed in any competitive industrial enterprise must, if the business is to survive, reduce costs by every means in his power. Even the greatest advocates of Government control have never suggested the elimination of competition in industry. He states that the only way the engineer can help to diminish unemployment is to create new products
\end{abstract}

for which there will be a demand. This will enable costs to be reduced, and at the same time the population will benefit by the improvement. He suggests, therefore, that economics be given a more prominent place in engineering education. Psychology is another subject of study that will assist the engineer in carrying on his work effectively under modern conditions. The question arises, in what way should the syllabuses of the colleges be best altered so as to accomplish this.

Mr. Hellmund has noticed that young engineers in industrial organizations frequently become so ab. sorbed in the solution of an interesting problem that they neglect to study its economic and commercial aspects. During the depression, it was more than ever necessary to focus attention on this side of the question. In many college curricula, courses in economics are included, but they are given by the department of economics, and much of the work covered at present is far removed from the practical applications encountered by the engineer in his everyday work. He concludes that the engineering schools should offer special abbreviated courses which show how the basic laws can be applied in practice. 